УДК 811.134 .3

\title{
Д.Л. Гуревич
}

\section{ПОНЯТИЕ «ЛЕКСИЧЕСКИЙ БРАЗИЛИЗМ» И ЕГО ИНТЕРПРЕТАЦИЯ}

Пиренейский и бразильский варианты португальского языка различаются по разным уровням языковой системы, в том числе и в лексике. Лексические отличия имеют как системный, так и вариативный характер. Системно противопоставлены лексемы, не имеющие регулярного и устойчивого употребления за пределами того национального варианта, в котором они встречаются. Вариативно противопоставлены лексемы, имеющие употребление за пределами национального варианта, в рамках которого они возникли, но частотность их употребления не сопоставима в сравниваемых вариантах. Традиционно системно противопоставленные лексемы, характерные для португальского языка Бразилии, носят название "brasileirismos" (бразилизмы), и как таковые фиксируются лексикографическими источниками и снабжаются соответствующими пометами. Вместе с тем большое количество лексем, обнаруживающих явно предпочтительное употребление в бразильском варианте, по сравнению с пиренейским, не имеет региональной пометы «бразилизм». На этом основании в статье делается вывод об аморфности понятия «бразилизм» в современной бразильской лексикографии и о континуальном характере бразилизмов, показывающих скорее тенденцию к употреблению в бразильском варианте, нежели обязательность.

Ключевые слова: лексические бразилизм, лексикография, португальский язык, бразильский вариант, языковая вариативность.

DOI: $10.35634 / 2412-9534-2019-29-3-398-407$

\section{1. Введение}

Лексический состав пиренейского (РЕ) и бразильского (PB) вариантов португальского языка весьма близок, но не полностью идентичен. Собственно лексические несовпадения, наряду с фонетическими особенностями, являются одними из наиболее ярких отличительных черт бразильского варианта (например, malta (PE) - turma; pessoal; galera (PB)). Зачастую только они присутствуют в поверхностных энциклопедических описаниях или дидактических пособиях, ориентированных на бразильский вариант или учитывающих его. При этом морфосинтаксические особенности, составляющие основу языковой системы, прагматико-дискурсивные особенности, маркирующие несовпадающие у португальцев и бразильцев черты речевого поведения, а также некоторые зоны так называемой языковой картины мира, связанные прежде всего с коннотативной интерпретацией языковых значений [É um grande trabalho (PE) - É um trabalhão (PB); Olá, bom dia (PE) - Tudo bem? (PB); Olá, viva $(P E)$ - Tudo beleza? (PB); tu - você], не менее разнообразны, но обнаруживаются при более глубоком погружении в существующий языковой узус.

Как отмечают практически все без исключения современные бразильские исследователи, национальные варианты португальского языка, являются вариантами нормы (понимаемой, в смысле Э. Косериу, как обязательные или регулярные в данном сообществе языковые реализации), а не вариантами системы (понимаемой как система открытых и закрытых путей в языке) - см., напр., [8. Р. 90-92; 3; 11; 19; 28; 5. Р. 966]. Таким образом, особенности бразильской языковой нормы включают, наряду с фактами языка, принадлежащими другим языковым уровням, характерные для Бразилии лексемы, то есть лексические бразилизмы.

При контрастном сопоставлении пиренейского и бразильского лексических корпусов обнаруживается нелинейное соотношение между формой и содержанием: у лексемы может совпадать означающее, но не означаемое, и наоборот. Так, например, у ряда лексем, совпадает форма, но не полностью совпадает содержание (bala - «пуля» (PE; PB) / «конфетка» (PB); banheiro - «спасатель на водах» (PE) / «туалет; ванная комната» (PB)). Вместе с тем, в обоих вариантах существуют лексемы (aeromoça / hospedeira - «стюардесса»), лексикализованные словосочетания (café da manhã / pequeno almoço) и фразеологизмы (programa de índio / coisa chata; encher o saco / chatear), противопоставленные по форме, но совпадающие по значению. Наряду с этим встречаются лексические предпочтения, характерные преимущественно (но не исключительно) для одного из национальных вариантов (xícara / chávena; camelô / vendedor ambulante). Таким образом, лексические бразилизмы не однородны и 
представляют собой не столько конечный список, сколько континуум, крайними точками которого являются, с одной стороны, лексемы, находящиеся в отношении дистрибуции (café da manhã / pequeno almoço), а с другой стороны лексемы и фразеологизмы общепортугальского фонда, обладающие большей частотностью в одном из вариантов. При этом бразильские и пиренейские словари по-разному интерпретируют бразилизмы или лузитанизмы из той части континуума, где не наблюдается жесткой дистрибуции ${ }^{1}$. Сопоставлению не всегда однозначной интерпретации лексемы на лексикографическом уровне и на уровне языкового употребления посвящена данная статья.

\section{2. Понятие «бразилизм» в бразильской лексикографии}

Необходимо учитывать, что понятие brasileirismo (бразилизм) начиная со второй половины XVIII в., когда оно возникло, и до середины XX в. не отделимо от понятия "marca dialectal"; "regionalism" (диалектная черта; регионализм). Само осмысление бразильского варианта во второй половине XIX начале XX века несло на себе печать культурологического и языкового национализма, или, как сейчас бы сказали, национальной самоидентификации. Его адептами были писатель-романтик Жозе де Аленкар, один из первых бразильских писателей, включавший в текст романов индейского цикла (Iracema; O guarani) большое количество индихенизмов; писатель-модернист Мариу де Андраде, поддерживавший понятие и термин «língua brasileira», автор так называемой Gramatiquinha - краткого описания бразильского варианта, охватывающего ряд языковых его особенностей от фонетики (в том числе и просторечных форм произношения типа abobra (abóbora); adevogado (advogado); fulô (flor) [21. Р. 436]) до синтаксиса и прагматики; литературный критик Тристау де Арарипе Жуниор, грамматисты Б.К. Алмейда Ногейра и Ж.Ж. Параньус да Силва, считавший, что поскольку бразильское произношение отличается от пиренейского, то и орфография должна иметь соответствующие отличия; лексикограф Антониу Жоаким де Маседу Соарес, к чьему словарю мы еще вернемся. Португальский язык Бразилии, который в современной лингвистической и научно-популярной литературе носит названия "português brasileiro"; "português do Brasil”; "variante brasileira", сторонники бразильской национальной идеи рубежа XIX-XX вв. называли по-разному: “dialeto brasileiro" (бразильский диалект) (Alencar, Macedo Soares, Araripe), "luso-brasileiro" (лузо-бразильский) (Macedo Soares, Almeida Nogueira, Paranhos da Silva), "lusoamericano" (лузо-американский), "nеoportuguês" (новопортугальский) (Araripe), "brasileiro", 'língua brasileira" (бразильский; бразильский язык) (Macedo Soares), или просто "nossa lingual” - «наш язык» [4. P. 70]. Кстати, понятие "nossa lingual" понимаемый именно как бразильский вариант португальского языка, встречается в современных бразильских грамматиках, например, в грамматике Pascuale Cipro Neto \& Ulisses Infante "Gramática da Língua Portuguesa" или в грамматике Carlos Henrique da Rocha Lima "Gramática Normativa da língua portuguesa" [23; 27], а также в названии популярной образовательной телепрограммы Nossa Língua Portuguesa, выходившей на канале TV Cultura.

Понятие «бразилизм», понимаемый прежде всего как лексический бразилизм, возникает достаточно рано. Уже в двуязычном португальско-английском словаре Антониу Виейры Транстагану 1773 г. (Anthony Vieira Transtagano. A Dictionary of the Portuguese and English languages, in two parts) встречаются бразилизмы двух типов: лексемы, имеющие индейское происхождение, и общепортугальские лексемы, расширившие свое значение за счет увеличения референтного поля. К бразилизмам первого типа относятся, например: jaboticaba [жаботикаба, бразильское виноградное дерево семейства миртовых], aipyi (совр. aipim) [сладкий маниок], или собственно mandioca [маниок]. К бразилизмам второго типа относятся: preguiça [животное ленивец], сарitania [в значении сарitania hereditária - единица административного членения колониальной Бразилии в XVI-XVIII вв.]. В качестве металингвистической пометы Транстагано использовал сочетание "in the Brasils" Характерно, что подобное региональное маркирование встречается в словаре, созданном почти за 50 лет до независимости Бразилии (1822) [26].

Позже, в 1824 г., Domingos Borges de Barros, бразильский сенатор и носитель титула Виконт де Педра-Бранка (Visconde de Pedra Branca), по которому он больше известен в Бразилии, написал пофранцузски для Этнографического атласа мира Адриана Бальби (Adriano Balbi. Atlas etnographique du

\footnotetext{
${ }^{1}$ Отметим, что нерегулярность использования словарных помет в тех случаях, когда имеет место вариативность языка в диатопии, не является исключительно свойством лузо-бразильской лексикографической традиции. Похожие затруднения возникают, например, у составителей современных словарей итальянского языка, где часть лексем одновременно принадлежит лексическому фонду итальянского литературного языка, с одной стороны, и диалектов Тосканы (в частности флорентийского), с другой [1].
} 
globe, 1826) небольшое сопоставительное исследование пиренейского и бразильского варианта португальского языка, включавшее два списка слов (около 50 лексем): 1) португальские слова, изменившие свое значение в Бразилии и 2) слова, употребляемые в Бразилии и неизвестные в Португалии. К первому списку отнесена, например, лексема faceira: «мясистое лицо» (РЕ) «кокетка» (PB). Ко второму списку - лексема quindim: сладкий десерт из сахара, яичного желтка и кокосового молока [18. Р. 428-429]. Как и в словаре Транстагано, в словнике Педра-Бранка бразилизмы разделены на те же два разряда.

Во второй половине XIX в. бразильский вариант португальского языка начинает подвергаться системной грамматизации, то есть включается в процесс, подразумевающий описание и инструментальный анализ языка с опорой на два базовых способа, которыми, собственно, являются грамматика и словарь [2. Р. 65].

К рубежу XIX-XX вв. Бразилия обретает собственную системную лексикографическую практику, отличную от португальской. Вплоть до 30 -х гг. XX в. описание бразильского лексического корпуса у ряда лексикографов строится на маркированном противопоставлении пиренейского и бразильского вариантов, и лексические бразилизмы интерпретируются прежде всего как бразильская языковая особенность [25. Р. 83].

В 1889 г. выходит словарь Маседу Соареса "Dicionário Brasileiro da Língua Portuguesa”, содержащий большое количество лексем (в последнем издании словаря 1954-1955 гг. около 4.000 бразилизмов), имеющих в Бразилии собственное значение. Это первый бразильский словарь с подробной проработкой лексики, не просто отмечающий списком имеющиеся бразилизмы, но ставящий бразильское значение, в случае его отличия от пиренейского, на первое место. [29]

Фактически, словарь Соареса лежит в русле работ других бразильских националистов, типа Теодоро Сампайо или того же Марио де Андраде, считавших существование бразильского языка фактом цивилизационной реальности. Неслучайно на форзаце словаря, фактически эпиграфом, помещена фраза, утверждающая примат устного бразильского узуса, противопоставленного письменной пиренейской норме: «Já é tempo dos brazileiros escreverem como se falla no Brazil, e não como se escreve em Portugal». Эта мысль, сформулированная в конце XIX в., стала лейтмотивом современной бразильской лингвистической мысли, вращающейся вокруг проблемы нормализации бразильского варианта и связанного с этим выбора базы нормы.

В 1899 г. выходит объемный словарь португальского лексикографа Кандиду де Фигейреду "Novo Diccionário da Língua Portuguesa". Словарь пережил несколько переизданий, последнее вышло в конце XX века. Фигейреду ставил целью охватить и пиренейский, и бразильский национальные варианты, о чем подробно говорит в предисловии, отмечая, что португальский язык принадлежит не только португальцам, но и бразильцам, и о том, что португальский язык Бразилии, который он называет "linguagem brasileira", не идентичен пиренейскому, поскольку испытал значительное влияние индейских языков тупи. Далее он добавляет, что словарь, адресованный всем говорящим попортугальски, не может обойти стороной бразильскую лексику, которую он оценивает приблизительно в 7.000 лексем, часть из которых заимствована из языков тупи, часть «создана» бразильцами, причем некоторое количество таких слов - это старопортугальская лексика, вышедшая из употребления к моменту создания словаря [14. P. v-vi].

В словаре Фигейреду впервые системно встречается региональная помета "Bras" - "termo brasileiro", причем с учетом региональных употреблений Bras. do N. (Brasileirismo do Norte); Bras. do S. (Sul); Bras. de Minas (Minas Gerais). Кроме того, Фигейреду был первым португалоязычным лексикографом, включившим термин "brasileirismo" в состав словаря в значении "expressão própria de brasileiros" (выражение, характерное для бразильцев).

Первым бразильским словарем, адресованным именно бразильской аудитории, был словарь Laudelino Freire "Grande e Novíssimo Dicionário da Língua Portuguesa", вышедший в 1939-1944 гг. в 5 томах и позже переиздававшийся в 1957 г.. Тот факт, что словарь был предназначен прежде всего для бразильцев, проявляется в отсутствии пометы "brasileirismo", притом что другие региональные пометы "lusitanismo"; "afrolusitanismo"; "asiolusitanismo" присутствуют [4]. Как пишет сам автор в предисловии, «непросто определить понятие бразилизм. Многие из них принадлежали языку бывших колонизаторов, другие встречаются в повседневной речи и, поскольку не были зафиксированы португальскими словарями, были сочтены бразилизмами» (перевод наш. - Д.Г.) [15].

Вышедший в 1961-1967 гг. объемный пятитомный академический словарь "Dicionário de língua portuguesa da Academia Brasileira de Letras" был составлен Антенором Нассентесом еще в 1940-х гг. 
охватывал около 100.000 лексем. В качестве образца был взят Словарь испанской королевской академии (DRAE). Понятие «бразилизм» как региональная помета встречается, но не всегда системно, автор главным образом опирается на своих предшественников. Популярностью словарь не пользовался и больше не переиздавался. Фактически попытка создать Академический словарь по европейским образцам потерпела неудачу в Бразилии, и все позднейшие авторитетные словари, имеющие полную и сокращенную версии, пережившие своих создателей и целый ряд переизданий, были авторскими: Dicionário Aurélio da Língua portuguesa; Dicionário Houaiss da Língua portuguesa; Dicionário de Usos do Português do Brail; Michaelis Dicionário Brasileiro da Língua Portuguesa. Большинство из них имеет пометы «бразилизм / лузитанизм», а некоторые, такие как Houaiss, Michaelis и Aulete, указывают на региональную распространенность отдельных бразилизмов.

\section{3. Границы понятия «бразилизм»}

Современные описания бразильского варианта нередко содержат списки семантических бразилизмов, которые понимаются как межвариантные синонимы, предполагающие семантическое соответствие между «лузитанской» и «бразильской» лексикой. Их составление носит сугубо утилитарный характер, поскольку анализируются не все значения лексемы, а только наиболее частотные, причем выбирается обычно бытовая лексика (erva (PE) - capim (PB); seis (PE) - meia (PB); autocarro (PE) ônibus (PB)). Такие списки характерны прежде всего для дидактических пособий, составленных обычно не бразильцами (см., например, [16]). Встречаются они и в лингвистических описаниях бразильского варианта, преследующих цели контрастивного сопоставления с пиренейским, в том числе, и в лексике, или в работах целенаправленно ориентированных на семантические особенности лексического состава бразильского варианта. Как и в случае с пособиями по изучению португальского языка, авторами сопоставительных работ, содержищих списки слов, нередко (но не только) являются иностранцы [22; 24; 5. Р. 973]. Тереза Бидерман приводит короткий список (80 лексем), не претендующий на всеохватность, однако перечисленные лексемы обладают наиболее высоким индексом частотности (muito VS imenso; terno VS fato; antigamente VS dantes; moça VS rapariga, etc). Монография Фолкера Нолля содержит список, содержащий около 300 лексем, относящихся также к высокочастотной лексике (aluguel VS renda; bagunça VS desordem; cobrador VS revisor; entrtanto VS contudo, etc). В диссертации В. Миохенена в приложении приводится список из 836 лексем, составленный с опорой на двуязычный португальско-финский словарь, оперирующий пометой бразилизм, не все они широко употребительны. Стоит отметить, что наличие тупинизмов или африканизмов, обозначающих природные или культурно-исторические реалии (aipim (вариант маниока; jiboia (водяной удав); berimbau (народный музыкальный инструмент); vatapá (блюдо)), для подобного списка бразилизмов не характерны. Обычно экзотизмы и их словарная трактовка составляют предмет описания именно в работах бразильских авторов (например, [7; 26]).

Вместе с тем, до сих пор не выработано сколько-нибудь универсального представления о том, что такое бразилизм. Отсутствие четкого представления приводит к вариативности в определении. Несмотря на то, что современные авторитетные бразильские словари определяют его приблизительно одинаково как 1) слово, словосочетание или выражение, характерное для португальского языка Бразилии; и 2) бразильская особенность в чертах характера, любовь ко всему бразильскому, синоним понятия "brasilidade" (Dicionário Aurélio; Dicionário Houaiss; Dicionário de Usos; Michaelis Dicionário), в лингвистической литературе встречаются более разнообразные толкования. В понятие "brasileirismo" могут включаться, помимо уже упомянутого: 1) этимология слова: индейская тупи-гуарани (то есть соотнесенная с языком племен, населявших непосредственно территорию современной Бразилии), общая американо-индейская (то есть соотнесенная с другими индейскими языками Америки) или африканская; 2) словоупотребления, характерные для пиренейского варианта раннего периода колонизации и вышедшие из употребления в современной Португалии, но сохранившиеся в Бразилии; 3) слова, получившие в бразильском варианте новое значение, дополнившее либо вытеснившее ранее существовавшее; 4) слова имеющие узко региональное употребление в самой Бразилии; 5) слова, характерные для разговорного или сниженного регистра речи носителей бразильского варианта - то, что называется попортугальски словом “gíria” или “calão”. [12]. Суммируя, можно сказать, что понятие «бразилизм» опирается на этимологию, семантику, региональный или функциональный узус, то есть учитывает диатопическое и диафазическое варьирование. Выбор каких-то одних компонентов и отказ от других определяет разносторонность в подходах исследователей. 


\section{4. Континуальность в семантике бразилизма}

Поскольку одним из основных критериев маркирования бразилизмов в современном языке является их узуальность, мы решили сконцентрироваться на сопоставлении данных словарей, с одной стороны, и данных, отражающих языковое употребление определенных лексем, с другой стороны. В качестве материала для анализа были взяты лексемы, входящие в ЛСГ «автомобиль», такие как рlaса; freio; caixa de marchas; carteira de motorista и др. Выбор данной ЛСГ объясняется тем, что она не связана с национально-культурной спецификой ни одной из стран и при этом включает в себя частотную и достаточно вариативную лексику, обычно не отмечаемую словарями как регионально маркированную - бразильскую или лузитанскую. Мы отобрали слова и словосочетания, не являющиеся, сугубо техническими терминами, и имеющие хотя бы один синоним. Дистрибуция таких синонимов по национальным вариантам оценивалась с опорой на три фактора: 1) встречаемость слова в словаре; 2) наличие региональной пометы «бразилизм» / «лузитанизм»; 3) индекс частотности по корпусу данных. В работе мы опирались на сведения четырех словарей: двух португальских и двух бразильских, две электронные и две бумажные версии для каждой пары словарей, два словаря авторские и два - коллективные. Португальские словари: Dicionário da língua portuguesa contemporánea (Academia das Ciências de Lisboa, составитель Malaca Casteleiro) (бумажная версия); Dicionário Priberam da Língua Portuguesa (электронная версия); бразильские словари: Dicionário Houaiss da Língua Portuguesa (издание 2009 г., составители Antônio Houaiss, Mauro de Salles Villar и Francisco Manuel de Mello Franco (бумажная версия); Michaelis Dicionário Brasileiro da Língua Portuguesa (электронная версия). Выбор словарей объясняется их ориентацией более чем на один национальный вариант, наличием региональных помет, подробной проработанностью лексем. Данные о частотности мы брали из электронного корпуса O Corpus do Português, составитель Mark Davies. Корпус, опирающийся преимущественно на тексты, опубликованные в Интернете, позволяет дифференцировать бразильские и португальские ресурсы. Общий объем корпуса составляет около 1 миллиарда словоупотреблений, из которых 655 миллионов приходятся на бразильскую часть и 326 миллионов - на португальскую. Поскольку объемы не совпадают, то для получения статистически значимых результатов мы применяли коэффициент «2». Всего было проанализировано 152 слова и словосочетания.

Наиболее значимые результаты анализа мы свели к таблице, которая отражает упоминание/неупоминание словарями слова или словосочетания в интересующем значении и индекс частотности в пиренейском и бразильском вариантах. В таблице используются следующие сокращения: HSS - Dicionáorio Houaiss da Língua Portuguesa; MCHL - Michaelis Dicionário Brasileiro da Língua Portuguesa; PRB - Dicionário Priberam da Língua Portuguesa; DLC - Dicionário da língua portuguesa contemporánea (Academia das Ciências de Lisboa); PB - Português Brasileiro; PE - Português Euripeu; + PB / +PE - наличие в словаре соответствующей региональной пометы.

\begin{tabular}{|c|c|c|c|c|c|c|}
\hline «номер машины» & HSS & MCHL & PRB & DLC & PB & $\mathrm{PE}$ \\
\hline chapa & $\begin{array}{c}+ \\
+ \\
\mathrm{PB}\end{array}$ & + & $\overline{+}+$ & + & 35 & 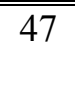 \\
\hline placa & + & + & + & - & 440 & 25 \\
\hline matrícula & - & - & + & + & 8 & 443 \\
\hline
\end{tabular}

«управлять / управление машиной»

\begin{tabular}{|l|c|c|c|c|c|c|}
\hline \hline & HSS & MCHL & PRB & DLC & PB & PE \\
\hline \hline dirigir & + & + & + & + & $\mathbf{8 1 1}$ & 102 \\
\hline guiar & + & + & + & + & 70 & 80 \\
\hline conduzir & + & + & + & + & 216 & $\mathbf{8 2 4}$ \\
\hline condução & + & + & + & + & 125 & $\mathbf{6 9 0}$ \\
\hline direção & + & - & - & - & $\mathbf{6 2 4}$ & 75 \\
\hline \hline
\end{tabular}


«водительские права»

\begin{tabular}{|l|c|c|c|c|c|c|}
\hline \hline & HSS & MCHL & PRB & DLC & PB & PE \\
\hline \hline carteira de motorista & + & + & $\begin{array}{c}+ \\
\text { PB }\end{array}$ & $\begin{array}{c}+ \\
\text { PB }\end{array}$ & $\mathbf{3 8 5}$ & 58 \\
\hline carteira de [nacional] habilitação & - & + & + & + & $\mathbf{7 2 4}$ & 21 \\
carta de condução & - & - & + & + & 22 & $\mathbf{1 6 5 4}$ \\
& & & PE & & & \\
\hline \hline
\end{tabular}

«тормоз; тормозить»

\begin{tabular}{|c|c|c|c|c|c|c|}
\hline & HSS & $\mathrm{MCHL}$ & PRB & DLC & PB & $\mathrm{PE}$ \\
\hline freio & + & + & ++ & $\begin{array}{c}+ \\
\text { PB }\end{array}$ & 208 & 9 \\
\hline travão & + & + & + & + & 5 & 77 \\
\hline breque (низкочастотный) & $\begin{array}{c}+ \\
\mathrm{PB}\end{array}$ & + & $\begin{array}{c}+ \\
\mathrm{PB}\end{array}$ & $\begin{array}{c}+ \\
\mathrm{PB} \\
\end{array}$ & 2 & 0 \\
\hline freio de mão & + & + & + & + & 131 & 3 \\
\hline freio de estacionamento & - & + & + & + & 36 & 0 \\
\hline freio de emergência & + & + & + & - & 7 & 1 \\
\hline travão de mão & - & - & + & + & 2 & 149 \\
\hline travão de emergência & - & - & + & + & 0 & 5 \\
\hline travão de estacionamento & - & - & + & + & 0 & 40 \\
\hline Frear & + & + & + & + & 65 & 2 \\
\hline travar & - & + & + & + & 10 & 80 \\
\hline brecar & + & + & $\begin{array}{c}+ \\
\mathrm{PB}\end{array}$ & $\begin{array}{c}+ \\
\mathrm{PB} \\
\end{array}$ & 10 & 0 \\
\hline
\end{tabular}

«сигнал аварийной остановки; фары»

\begin{tabular}{|l|c|c|c|c|c|c|}
\hline \hline & HSS & MCHL & PRB & DLC & PB & PE \\
\hline \hline pisca alerta & - & - & + & - & $\mathbf{2 7}$ & 1 \\
& & & PB & & \\
\hline luzes de perigo & - & - & - & - & 1 & $\mathbf{1 7}$ \\
\hline quatro piscas & - & - & - & - & 0 & $\mathbf{2 3}$ \\
\hline pisca / pisca-pisca & + & + & + & + & 72 & 37 \\
\hline farol alto & - & - & - & - & $\mathbf{5 0}$ & 2 \\
\hline farol de milha & - & - & - & - & 12 & 0 \\
\hline farol baixo & - & - & - & - & $\mathbf{3 9}$ & 0 \\
\hline farois médios & - & - & - & - & 0 & 7 \\
\hline farois máximos & - & - & - & - & 0 & 16 \\
\hline \hline
\end{tabular}

«коробка передач; передача; переключатель передач»

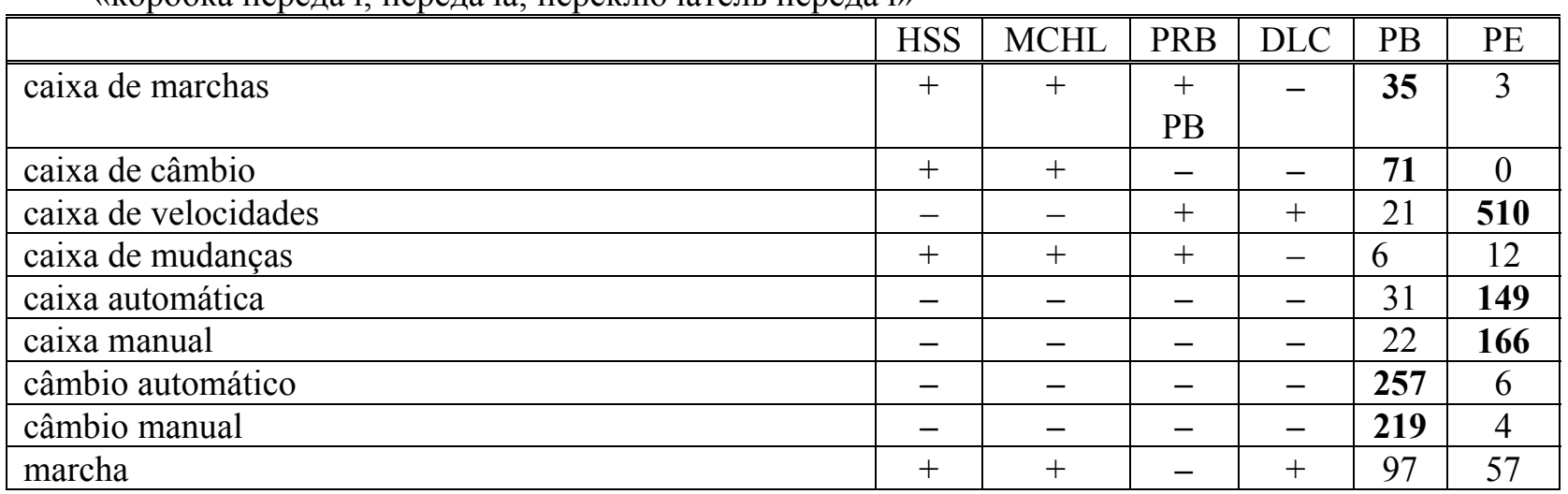




\begin{tabular}{|l|c|c|c|c|c|c|}
\hline & & & & PB & & \\
\hline câmbio & + & + & - & - & $\mathbf{5 2}$ & 3 \\
\hline mudança & + & - & - & + & 1 & $\mathbf{3 5}$ \\
\hline ponto morto & + & + & + & + & 101 & 102 \\
\hline alavanca de câmbio & + & + & - & - & $\mathbf{5 5}$ & 3 \\
\hline alavanca de marchas & + & - & - & - & 6 & 0 \\
\hline alavanca de mudanças & + & + & - & + & 8 & 18 \\
\hline alavanca de velocidades & - & - & - & - & 0 & 19 \\
\hline \hline
\end{tabular}

«парковка; парковаться»

\begin{tabular}{|c|c|c|c|c|c|c|}
\hline & HSS & MCHL & PRB & DLC & $\mathrm{PB}$ & $\mathrm{PE}$ \\
\hline estacionamento & + & + & + & $\begin{array}{c}+ \\
\mathrm{PB}\end{array}$ & 301 & 281 \\
\hline parque de estacionamento & - & - & + & + & 35 & 778 \\
\hline parqueamento & $\begin{array}{c}+ \\
\mathrm{PB}(!)\end{array}$ & + & + & + & 11 & 233 \\
\hline estacionar & + & + & + & + & 1128 & 2179 \\
\hline parquear & + & + & + & + & 1 & 16 \\
\hline deixar (o) carro no estacionamento & - & - & - & - & 57 & 7 \\
\hline aparcar & - & - & + & + & 1 & 5 \\
\hline
\end{tabular}

«автомобиль; машина»

\begin{tabular}{|l|c|c|c|c|c|c|}
\hline & HSS & MCHL & PRB & DLC & PB & PE \\
\hline \hline carro & + & + & + & + & 61313 & 45782 \\
\hline veículo & + & + & + & + & 16247 & 12708 \\
\hline automóvel & + & + & + & + & 3660 & $\mathbf{1 2 7 9 8}$ \\
\hline viatura & + & + & + & + & 1430 & $\mathbf{4 8 4 7}$ \\
\hline
\end{tabular}

«водитель»

\begin{tabular}{|l|c|c|c|c|c|c|}
\hline \hline & HSS & MCHL & PRB & DLC & PB & PE \\
\hline \hline motorista & + & + & + & + & 17364 & 14599 \\
\hline condutor & + & + & + & + & 6331 & $\mathbf{2 0 9 0 2}$ \\
\hline chofer & + & + & + & + & $\mathbf{3 4 3}$ & 40 \\
\hline \hline
\end{tabular}

Как показывают данные, наличие региональных помет, если они есть, обычно совпадает с данными корпуса. Так, термин “carteira de habilitação” имеет преобладающий индекс частотности в бразильском варианте и помечен двумя словарями как бразилизм (любопытно, что такую помету дают именно португальские, а не бразильские словари); термин “carta de condução” показывает более высокий индекс для пиренейского варианта и также обладает соответствующей пометой. Однако у большинства рассмотренных лексем региональные пометы отсутствуют, притом что корпус показывает явную тенденцию к предпочтению употребления в том или ином национальном варианте (condutor chofer; veículo - automóvel). Вместе с тем, фиксируя саму лексему, словари часто не отмечают ее региональное значение, обычно это касается значений, характерных для противоположного варианта (португальские словари относительно бразильского варианта и наоборот). Отказ от фиксации словарем нехарактерного, с точки зрения составителей, регионально зависимого значения как правило коррелирует с его низкой или нулевой частотностью в том национальном варианте, для которого, прежде всего, и создавался словарь. Например, сочетание “parque de estacionamento" (парковка), имеет преобладающую частотность в пиренейском варианте и упомянуто в португальских, но не в бразильских словарях. Ряд словосочетаний вообще не имеет словарной фиксации (например, саіха automática câmbio automático), однако явный перевес по частотности свидетельствует о том, что это складывающиеся лузитанизм и бразилизм, соответственно. Обобщая, можно сказать, что индекс частотности показывает тенденцию к регионально ориентированному употреблению какой-либо лексе- 
мы, которая не маркирована словарями как бразилизм / лузитанизм. Так, например, лексема са̂mbio в значении «переключение скоростей» становится почти исключительно фактом бразильского узуса с перевесом по частотности в зависимости от сочетания в 20-70 раз, оставляя пиренейскому варианту в качестве лексических предпочтений саixa; velocidades; mudança(s); и это притом что вне контекста частотность лексемы câmbio в бразильском варианте выше всего в 3,5 раза, а не в десятки раз.

\section{5. Выводы}

Итак, сопоставляя данные словарей и узуса, мы приходим к ряду выводов. Во-первых, аморфность понятия «бразилизм», не преодоленная в португальской и бразильской лексикографии до сих пор, обнаруживает себя в несистемном распределении региональных помет у одних и тех же лексем в разных словарях. Во-вторых, словари фиксируют преимущественно «состоявшиеся» бразилизмы, обладающие устойчивым регионально ориентированным значением, подкрепленным частотностью в узусе. При этом формирующиеся бразилизмы, допускающие реализацию в обоих вариантах, но показывающих явное предпочтение именно в бразильском узусе, словарями фиксируются как существующие лексемы или словосочетания, но не снабжаются пометами. В-третьих, противопоставление по частотности, если лексема входит в минимальный синонимический ряд, имеет место почти всегда, что говорит о приоритетном словоупотреблении в разных национальных вариантах слов с близким или практически идентичным значнием, типа freio de mão $(\mathrm{PB}) \sim$ travão de mão (PE); câmbio automático (PB) caixa automática (PE). Вместе с тем, несовпадение в употреблении не абсолютно, то есть не точечно, а градуально: для одних лексем встречаемость в одном из вариантов близка или равна нулю, для других отлична от нуля и говорит о предпочтении/тенденции в употреблении, но не о запрете на него. Случаев нулевого употребления немного, около 13 \%. Таким образом, на том основании, что семантические бразилизмы нередко образуют не столько бинарные оппозиции с соответствующими им по значению лузитанизмами, сколько градуальные, то есть, противопоставлены скорее по регулярности/нерегулярности употребления, а не по наличию/отсутствию в узусе, можно сделать вывод о континуальном характере бразилизмов, входящих в закрытую лексико-семантическую группу. Это означает, что значительная часть лексического корпуса бразильского варианта португальского языка обнаруживает вариативность в том, что касается языковой нормы, но не языковой системы, поскольку «бразильское» значение лексемы, характерное для этого варианта, не воспринимается носителями пиренейского варианта как совершенно чуждое и непонятное, а скорее как редкое и нехарактерное.

\section{СПИСОК ЛИТЕРАТУРЫ}

1. Жолудева Л.И. Лексические тосканизмы и их функционирование в итальянских комедиях XVI века // Древняя и Новая Романия. 2017. № 19. С. 39-49.

2. Auroux S. A revolução tecnológica da grammatização. Trad. Eni Puccinelli Orlandi. Campinas: Editora da UNICAMP, 1992. P. 136.

3. Bagno M. (org). Linguística da norma. São Paulo: Edições Loyola, 2004. P. 356.

4. Biderman M.T.C. A formação e a consolidação da norma lexical e lexicográfica no português do Brasil // Nunes J.H.; Petter M. (Orgs.) História do saber lexical e constituição de um léxico brasileiro. São Paulo: Humanitas, 2002. P. 253.

5. Biderman M.T.C. O português brasileiro e o português eurpeu: identidade e contrastes // Revue belge de philologie et d'histoire. 2001. Tome 79, fasc. 3. P. 963-975.

6. Borba F. da Silva, Ignácio S.E. Dicionário de Usos do Português do Brasil. São Paulo: Editora Atica, 2002. P. 1674.

7. Carmo L.A.F. O léxico do Brasil em dicionários de língua portuguesa do século XIX. Tese (Doutorado). Universidade do Estado do Rio de Janeiro. Instituto de Letras. Rio de Janeiro, 2015. P. 339.

8. Castilho A.T. de. Nova gramática do português brasileiro. São Paulo, Editora Contexto, 2010. P. 768.

9. Dicionário da Língua Portuguesa Contemporânea da Academia das Ciências de Lisboa. Lisboa: Verbo, 2001. P. 3809.

10. Dicionário Priberam da Língua Portuguesa. [Электронный pecypc]. URL: https://www.priberam.pt/dlpo

11. Faraco C.A. Norma culta brasileira: desatando alguns nós. São Paulo: Parábola Editorial, 2008. P. 205.

12. Faulstich E. Duas questões em discussão: O que são brasileirismos nos dicionários de Língua Portuguesa? Existem brasileirismos terminológicos? // Jornada sobre "Variación Geolectal i Terminologia". Red Panlatina de Terminología Realiter / IULAterm. Institut Universitari de Lingüística Aplicada. Barcelona, Espanha. 24 de novembro de 2004. [Электронный pecypc]. URL: http://www.realiter.net/spip.php?article209

13. Ferreira A.B.H. Dicionário Aurélio da lingua portuguesa. (5a ed.). Curitiba, 2010. P. 2272.

14. Figueiredo C. de. Novo Diccionário da Língua Portuguesa. Lisboa: Teixeira, 1913. P. 2151.

15. Freire L. Grande e Novíssimo Dicionário da Língua Portuguesa. Rio de Janeiro: Livraría José Olympio, 1954. 5 Vols. 
16. Hampl Z., Hoblik J. Učebnice Portugalštiny. Praha: Státní pedagogické nakladatelství. 1965. P. 611.

17. Houaiss A., Villar M.S. Dicionário Houaiss da língua portuguesa. Rio de Janeiro, 2009. P. 1986.

18. Isquerdo A.N. A propósito de dicionários de regionalismos do português do Brasil. In: Isquerdo, Aparecida Negri; Alves, Leda Maria (orgs). As ciências do léxico. Lexicologia. Lexicografia. Terminologia. Vol. III. Campo Grande: Editora UFMS, 2007. P. 483.

19. Lucchesi D.A Teoria da Variação Linguística: um balanço crítico. // Estudos linguísticos. São Paulo, 41 (2), 2012. P. 793-805.

20. Michaelis Dicionário Brasileiro da Língua Portuguesa. [Электронный pecypc.] URL: http://michaelis.uol.com.br/ moderno-portugues

21. Moreira B. E. da Costa. Redescobrindo os brasileirismos. In: Filologia e Linguística portuguesa. São Paulo, v. 18, n. 2. P. 421-442.

22. Myöhänen V. Em busca de contrastes léxico-semânticos luso-brasileiros. Dissertação de Mestrado em Filologia Portuguesa. Departamento de Línguas Modernas. Universidade de Helsinque, 2017. P. 166.

23. Neto C.P.; Infante U. Gramática de língua portuguesa. São Paulo: Scipione, 1998. P. 583.

24. Noll V. O português brasileiro: formação e contrastes. (Trad. do alemão.) São Paulo: Globo, 2008. P. 400.

25. Oliveira S.E. de. Um espaço de enunciação para dizer os brasileirismos. In: Nunes, José Horta; Petter, Margarida (Orgs.). História do saber lexical e constituição de um léxico brasileiro. São Paulo: Humanitas, 2002. P. 253.

26. Oliveira A.S. Léxico brasileiro em dicionários monolíngues e bilíngues: estudo metalexicográfico da variação em perspectiva dialetal e histórica. Tese (Doutorado). Universidade Federal da Bahia. Salvador, 2017. P. 354.

27. Rocha Lima C.H. Gramática normativa da língua portuguesa (49a edição). Rio de Janeiro: José Olympio, 2011 (1945). P. 655.

28. Silva R.V.M. Orientações atuais da lingüística histórica brasileira. In: D.E.L.T.A., Vol. 15, número especial, 1999. P. 147-166.

29. Soares A.J.M. Diccionario Brazileiro da Lingua Portugueza. Publicação da Biblioteca Nacional. Rio de Janeiro: Typ. de G. Leuzinger \& Filhos, 1889. P. 147.

Поступила в редакцию 06.05.2019

Гуревич Дмитрий Львович, кандидат филологических наук, доцент кафедры иберо-романского языкознания филологического факультета МГУ имени М.В. Ломоносова 119991 Россия, г. Москва, Ленинские горы, д. 1, стр. 51

E-mail: caipira@yandex.ru

\section{D.L. Gurevich}

\section{THE NOTION “LEXICAL BRAZILIANISM” AND ITS INTERPRETATION}

DOI: $10.35634 / 2412-9534-2019-29-3-398-407$

European and Brazilian variants of Portuguese differ from one another on different levels, including lexis. Lexical divergences can be either of systemic or of variational nature. One can speak of systemic oppositions when the lexemes in question are not regularly used outside the national variant they belong to. Variational opposition presupposes that the lexemes opposed are used in both variants but their frequency differs considerably. Traditionally, the words that make up the Brazilian pole of systemic oppositions are called "brasileirismos" ("brazilianisms"), which is reflected in lexicographic sources by means of special sigla. However, a considerable number of lexemes that are obviously preferred by Brazilian Portuguese speakers (in contrast to the European Portuguese language community) are not accompanied by the corresponding sigla. This fact makes us believe, firstly, that the notion "brazilianism" in modern Brazilian lexicography is still vague, and, secondly, that lexical oppositions between European and Brazilian Portuguese are of continuous nature, that is, their preferential use in Brazil is rather a tendency than a necessity.

Keywords: lexical brazilianisms, lexicography, Portuguese language, Brazilian Portuguese, language variation.

\section{REFERENCES}

1. Zholudeva L.I. Leksicheskie toskanizmy i ih funkcionirovanie $v$ ital'janskih komedijah XVI veka [Lexical tuscanisms and their functioning in XVI-century Italian comedies] // Drevnjaja i Novaja Romanija [Old and New Romania]. 2017. № 19. P. 39-49.

2. Auroux S. A revolução tecnológica da grammatização. Trad. Eni Puccinelli Orlandi. Campinas: Editora da UNICAMP, 1992. P. 136. 
3. Bagno M. (org). Linguística da norma. São Paulo: Edições Loyola, 2004. P. 356.

4. Biderman M.T.C. A formação e a consolidação da norma lexical e lexicográfica no português do Brasil // Nunes J.H.; Petter M. (Orgs.) História do saber lexical e constituição de um léxico brasileiro. São Paulo: Humanitas, 2002. P. 253.

5. Biderman M. T. C. O português brasileiro e o português eurpeu: identidade e contrastes // Revue belge de philologie et d'histoire. 2001. Tome 79, fasc. 3. P. 963-975.

6. Borba F. da Silva, Ignácio S.E. Dicionário de Usos do Português do Brasil. São Paulo: Editora Atica, 2002. P. 1674.

7. Carmo L.A.F. O léxico do Brasil em dicionários de língua portuguesa do século XIX. Tese (Doutorado). Universidade do Estado do Rio de Janeiro. Instituto de Letras. Rio de Janeiro, 2015. P. 339.

8. Castilho A.T. de. Nova gramática do português brasileiro. São Paulo, Editora Contexto, 2010. P. 768.

9. Dicionário da Língua Portuguesa Contemporânea da Academia das Ciências de Lisboa. Lisboa: Verbo, 2001. P. 3809.

10. Dicionário Priberam da Língua Portuguesa. [Электронный pecypc]. URL: https://www.priberam.pt/dlpo

11. Faraco C.A. Norma culta brasileira: desatando alguns nós. São Paulo: Parábola Editorial, 2008. P. 205.

12. Faulstich E. Duas questões em discussão: O que são brasileirismos nos dicionários de Língua Portuguesa? Existem brasileirismos terminológicos? // Jornada sobre "Variación Geolectal i Terminologia». Red Panlatina de Terminología Realiter / IULAterm. Institut Universitari de Lingüística Aplicada. Barcelona, Espanha. 24 de novembro de 2004. [Электронный pecypc]. URL: http://www.realiter.net/spip.php?article209

13. Ferreira A.B.H. Dicionário Aurélio da lingua portuguesa. (5a ed.). Curitiba, 2010. P. 2272.

14. Figueiredo C. de. Novo Diccionário da Língua Portuguesa. Lisboa: Teixeira, 1913. P. 2151.

15. Freire L. Grande e Novíssimo Dicionário da Língua Portuguesa. Rio de Janeiro: Livraría José Olympio, 1954. 5 Vols.

16. Hampl Z., Hoblik J. Učebnice Portugalštiny. Praha: Státní pedagogické nakladatelství. 1965. P. 611.

17. Houaiss A., Villar M.S. Dicionário Houaiss da língua portuguesa. Rio de Janeiro, 2009. P. 1986.

18. Isquerdo A. N. A propósito de dicionários de regionalismos do português do Brasil. In: Isquerdo, Aparecida Negri; Alves, Leda Maria (orgs). As ciências do léxico. Lexicologia. Lexicografia. Terminologia. Vol. III. Campo Grande: Editora UFMS, 2007. P. 483.

19. Lucchesi D. A Teoria da Variação Linguística: um balanço crítico. // Estudos linguísticos. São Paulo, 41 (2), 2012. P. 793-805.

20. Michaelis Dicionário Brasileiro da Língua Portuguesa. [Электронный pecypc.] URL: http://michaelis.uol.com.br/ moderno-portugues

21. Moreira B. E. da Costa. Redescobrindo os brasileirismos. In: Filologia e Linguística portuguesa. São Paulo, v. 18, n. 2. P. 421-442.

22. Myöhänen V. Em busca de contrastes léxico-semânticos luso-brasileiros. Dissertação de Mestrado em Filologia Portuguesa. Departamento de Línguas Modernas. Universidade de Helsinque, 2017. P. 166.

23. Neto C.P.; Infante U. Gramática de língua portuguesa. São Paulo: Scipione, 1998. P. 583.

24. Noll V. O português brasileiro: formação e contrastes. (Trad. do alemão.) São Paulo: Globo, 2008. P. 400.

25. Oliveira S.E. de. Um espaço de enunciação para dizer os brasileirismos. In: Nunes, José Horta; Petter, Margarida (Orgs.). História do saber lexical e constituição de um léxico brasileiro. São Paulo: Humanitas, 2002. P. 253.

26. Oliveira A.S. Léxico brasileiro em dicionários monolíngues e bilíngues: estudo metalexicográfico da variação em perspectiva dialetal e histórica. Tese (Doutorado). Universidade Federal da Bahia. Salvador, 2017. P. 354.

27. Rocha Lima C.H. Gramática normativa da língua portuguesa (49a edição). Rio de Janeiro: José Olympio, 2011 (1945). P. 655.

28. Silva R.V.M. Orientações atuais da lingüística histórica brasileira. In: D.E.L.T.A., Vol. 15, número especial, 1999. P. 147-166.

29. Soares A.J.M. Diccionario Brazileiro da Lingua Portugueza. Publicação da Biblioteca Nacional. Rio de Janeiro: Typ. de G. Leuzinger \& Filhos, 1889. P. 147.

Received 06.05.2019

Gurevich D.L., Candidate of Philology, Associate Professor at Department of Ibero-Romance linguistics Lomonosov Moscow State University

Faculty of Philology

119991, 1-51 Leninskie gory, Moscow, Russia

E-mail: caipira@yandex.ru 